\title{
CSAE WPS/2008-28
}

\section{"Monetary Policy and Inflation Modeling in a more Open Economy in South Africa."}

\author{
JANINE ARON \\ Department of Economics, Oxford \\ AND \\ JOHN MUELLBAUER \\ Nuffield College, Oxford
}

4 September, 2008

\begin{abstract}
South Africa in the 1990s became globally more integrated after years of isolation. Opening the trade and capital accounts gave impetus to a monetary policy regime change to inflation targeting from 2000, after a costly transitional period of monetary mismanagement with low policy transparency. Changes in openness can, however, disrupt the inflation forecasting on which targeting monetary policies depend. This chapter demonstrates how the central bank's own producer price inflation equation in its core model can be improved by taking account of greater openness, using both innovative time-series openness measures and a more conventional measure. The model has a greatly improved fit and stability over longer samples when also including the real exchange rate and the interest rate differential (making explicit the exchange rate channel of monetary transmission) and asymmetric food price inflation. Moreover, there is a role for the level of the output gap rather than simply a short-run effect, as in the central bank's model. This helps mitigate the arguments in current South African debate regarding the apparent unconcern of inflation targeting policy for the level of economic activity.
\end{abstract}

\footnotetext{
*Forthcoming chapter in New Monetary Policy Frameworks for Emerging Markets: Coping with the Challenges of Financial Globalization, Gill Hammond, Ravi Kanbur and Eswar Prasad (eds.), Bank of England/Edward Elgar (forthcoming book, 2009). The authors acknowledge funding support from the Economic and Social Research Council, U.K. (grant RES-000-22-2066). We are grateful for advice from Brian Kahn (South African Reserve Bank), Gavin Keeton (Anglo American), and Andre Hermans (South African Parliament) and Bent Nielsen (Nuffield College, Oxford).
} 


\section{Introduction}

South Africa (SA) in the 1990s became globally more integrated after years of isolation through trade and financial sanctions, prohibitive trade policies and a mainly closed capital account. The cessation of sanctions beginning in the early 1990s with an improved political dispensation in prospect, the gradual opening of the trade and capital accounts and the concomitant emergence of SA as a desirable emerging market destination for investors, gave impetus to a monetary policy regime change to inflation targeting from early 2000 . The preceding monetary regime in the 1990s was founded on outmoded and dysfunctional monetary targeting, and was hampered by unclear policy objectives and poor policy transparency. With the opening of the economy, conflicting policy goals lead to costly monetary mismanagement, hampering growth. The adoption of an inflation targeting regime in a more open economy aimed to enhance policy transparency, accountability and predictability, and align monetary policy more closely with widespread international practice. The inflation targeting regime (supported by fiscal policy) has successfully enhanced the credibility and effectiveness of monetary policy, achieving greater macro-stability and reducing inflation (Aron and Muellbauer, 2005, 2007a, 2008). SA's international economic standing has consequently improved, evidenced by reduced sovereign risk spreads and improved debt ratings, while investment and growth have risen.

However, changes in openness can disrupt the inflation forecasting on which targeting monetary policies depend. Since lowering import barriers typically exerts downward pressure on prices, evolving openness represents a structural break from the inflation forecasting perspective. Omitting this factor can confuse modellers studying the determinants of inflation and output. For instance, a greater degree of openness due to trade liberalisation is likely to lower the rate of inflation and may alter the influence of the real exchange rate on growth, via the impact on the demand for exports and leakage of demand into imports. Unfortunately, attempts to measure trade policy are fraught with measurement problems for observable components (such as tariffs), and by the presence of difficult-to-quantify components of policy, such as quotas and other non-tariff barriers (see empirical survey of trade policy measures in Aron and Muellbauer, 2007b).

We demonstrate the importance of accounting for this structural change in modeling SA inflation, using innovative time-series openness measures that address some of the shortcomings of existing measures. Including the openness measures in the central bank's own inflation model produces 
more stable equations and over longer periods. It also allows a role for the level of the output gap rather than only its change, with policy implications relevant to current debate.

This chapter first summarises the trade liberalisation from 1990 and freeing of the capital account, suggesting the challenges posed for monetary policy of greater trade and capital account openness. In section 3, we explain the derivation of innovative measures capturing greater openness (details in Aron and Muellbauer, 2007b), and in section 4, show improved results in various dimensions for the wholesale price inflation model of the South African Reserve Bank (SARB) when these openness measures are included. Further improvements in the model result when the real exchange rate, the international interest rate differential and food prices are introduced, as suggested by our previous work (Aron et al., 2003; and Aron and Muellbauer, 2007b).

\section{Greater economic openness and the impact on monetary policy}

SA's trade was heavily protected from before the 1960s. There have been extensive changes in SA trade policy especially since the early 1990s, and a greater openness to capital inflows from 1995. Externally imposed trade and financial sanctions in the 1990s, first applied after 1976, were also lifted in the 1990s, mainly after the democratic elections. This structural change - the greater openness associated with the international reintegration of the democratic SA - has significantly influenced the conduct and design of monetary policy in SA.

\section{Greater openness in the current and capital accounts}

SA's extensive trade liberalization since 1990 is outlined in Edwards et al. (2009). ${ }^{1}$ Conventional measures of openness based on real trade ratios and price ratios (Aron and Muellbauer, 2007b) suggest the most trade restrictive period was 1980-85, followed by a substantial liberalisation from the early 1990s with the removal of remaining quotas and a decline in tariffs. From 1983, quotas were replaced by equivalent import tariffs with the share of imports subject to quotas falling to below 15 percent by 1992. However, tariffs were flexible upwards in replacing quotas and their coverage was pervasive. The liberalising effect of dismantling quotas was also partly offset by the imposition of periodic import surcharges. Particularly after the 1985 debt crisis, the

\footnotetext{
${ }^{1}$ For a description of earlier trade liberalising episodes, see also Edwards (2005).
} 
government ensured current account surpluses through import surcharges to help meet foreign debt repayments. These were eventually abolished in 1994-1995. SA's reintegration with international and regional communities after the democratic elections heralded several multilateral and bilateral trade agreements that instituted tariff reduction for the first time, beginning with the GATT Uruguay round of 1994. Quotas and export subsidies were also eventually largely phased out by 1997 .

The question as to whether these tariff reforms achieved a reduction of effective rates of protection of industry has been contentious, see Edwards (2005). Using a consistent set of tariff data for 1988-2004, Edwards finds significant reductions in nominal and effective protection during the 1990s, both in terms of average nominal protection and effective protection in manufacturing, including the import surcharges but excluding non-tariff barriers (through lack of ad valorem equivalents for these). Reductions in protection occurred in almost all traded sectors.

The impact on monetary policy of the rapid opening of the current account from 1990, and virtual cessation by 1995 of sanctions was two-fold. The key effects of tariff reduction and other aspects of opening the economy to trade would be expected to be seen in improved productivity figures for traded sectors under competition, and also in the impact on inflation. Indeed, the surge in labour productivity in the manufacturing sector coincides with greater trade openness. It seems likely too that greater trade openness could cause a shift in the relative importance of the different channels by which monetary policy operates, for example the real exchange rate channel. There is evidence for an increase in the role of the real exchange rate in influencing growth of GDP, Aron and Muellbauer (2002a).

SA's capital account had been subject to controls from before the 1960s. From the second quarter of 1979, a dual-currency exchange rate regime with commercial and financial rand exchange rates $^{2}$ was adopted, with a brief abortive period of unification in 1983 to 1985 (details in Aron, Elbadawi and Kahn, 2000). There was little access to international finance in the sanctions era after 1976, especially after 1985, except for some trade finance, but after the 1994 elections capital flows increased strongly. Flows, and particularly short-term flows, further accelerated with the effective lifting of exchange controls on non-residents in March, 1995, when the dual

\footnotetext{
2 The intended impact of the financial rand was to break the direct link between domestic and foreign interest rates, as well as to insulate the capital account from certain categories of capital flows. The financial rand applied to most non-resident portfolio flows and direct investment.
} 
exchange rate regime was finally successfully unified to a managed float. The change from negligible capital inflows to a substantial positive net inflow after 1994 reflected SA's status as a leading emerging market. This structural shift in the size of sustainable flows required adjustment via a "permanently" more appreciated real exchange rate (unless offset by liberalisation of exchange controls on residents).

By contrast with the sudden lifting of controls on non-resident flows, controls on residents were only gradually liberalized under the democratic government, and some controls remain. Chronological details can be found in Leape and Thomas (2009), who characterize the process as avoiding large and potentially destabilizing capital flight in a transitional period. Greater reform has occurred in periods of capital inflows, but has moderated during periods of instability and capital outflows. The pace of reform has been influenced by the continuing need for effective regulatory instruments for macroeconomic risk management, especially concerning SA's large institutional investors.

The monetary implications of the more open capital account obviously depend on the monetary rule followed, and the sequencing of the lifting of domestic exchange controls. In principle, one impact on monetary policy of the sudden liberalization of non-resident capital controls should arise from a dramatic readjustment of the sustainable level of inflows with upward pressure on the exchange rate. On the other hand, a liberalisation of the pervasive exchange controls on residents would be expected to have the opposite effect on the exchange rate. If the rule was to stabilize inflation and the exchange rate floated freely and appreciated, the deflationary effect would give the opportunity to reduce domestic interest rates and perhaps moderate the inflows. A clear prioritisation of monetary policy objectives is important because, for instance, with an open capital account and persistent capital outflows, a policy trade-off can arise where sustaining an exchange rate "target" occurs at the expense of higher inflation, higher interest rates and eventually reduced output (e.g. Obstfeld, 1996).

\section{SA monetary regimes and their evolution with greater openness}

In Table 1, we summarise the key features and their evolution of the two consecutive monetary policy regimes that coincided with the period of greater openness in SA after $1990 .^{3}$ The table

\footnotetext{
${ }^{3}$ This section draws on a few of our recent papers: Aron and Muellbauer (2002b, 2005, 2007a, 2008, 2009).
} 
contrasts, inter alia, the transparency and accountability of the two frameworks. We discuss below the costly consequences of poor monetary policy transparency and accountability under the first framework in the transition to a more open economy, especially after 1995. We argue this led to the adoption of an inflation targeting regime from 2000, to enhance policy transparency, accountability and predictability.

Since 1986 there have been two monetary policy regimes in SA. ${ }^{4}$ Monetary target ranges, by then already effectively abandoned by the UK and US, were announced annually from 1986 to 1998 , though any usefulness of these targets had been sharply diminished by extensive domestic financial liberalisation beginning in the 1980s (Aron and Muellbauer, 2002b) and the later resurgence of capital inflows. From 1990, the monetary guidelines were supplemented by an eclectic set of indicators, including the exchange rate, asset prices, output gap, balance of payments, wage settlements, total credit extension, and the fiscal stance (Stals, 1997). The policy rule under money targeting was thus not transparent, with a range of potential indicators influencing policy in addition to money targets, but without known weights. ${ }^{5}$ This diminished the accountability of the SARB.

By contrast with the detailed fiscal policy objectives toward greater transparency and accountability in the government's RDP and GEAR plans ${ }^{6}$, rather cursory treatment was given to monetary policy. The plans and the Interim and Final Constitutions ${ }^{7}$ expressed the monetary policy objectives differently, and until mid-1996 there was no clear prioritisation amongst the objectives (see Table 1). There was also a lack of transparency about the extent of forward foreign exchange market intervention (in the absence of significant reserves).

Policy actions during 1994 to 1998 were often highly questionable. Aron and Muellbauer (2007a) argue that Governor Stals had dual and conflicting objectives for monetary policy objectives from April, 1994, and despite official claims that the exchange rate was freely floating, engaged in heavy intervention in the period of resumption of capital inflows to restrain appreciation, and

\footnotetext{
${ }^{4}$ For earlier regimes, see Gidlow (1995a,b) and Aron and Muellbauer (2002b).

${ }^{5}$ Aron and Muellbauer (2002b) apply an extension of the Taylor Rule model (Taylor, 1993) to try to estimate the weights applied to different policy objectives in the interest rate rule during 1986-97.

${ }^{6}$ Following elections in April, 1994, the initial objectives of macroeconomic policy were contained in two highly publicised macro-policy plans The broad goals of the Reconstruction and Development Programme (RDP) launched in January, 1994, were reinforced by the Government's Growth, Employment and Redistribution strategy (GEAR), announced in June 1996. These plans are available on the web, and see also Hirsch (2005) and Nowak and Ricci (2005).

${ }^{7}$ An Interim Constitution was adopted in 1994 and the Final Constitution in December 1996.
} 
again to stem depreciation in the currency crises of 1996-1998. Much intervention occurred via forward foreign exchange contracts (Kahn and Leape, 1996), and proved extremely costly to the fiscus. The high levels of policy interest rates severely damaged economic growth and curtailed investment. With growth falling to half a percent in real terms during 1998, this monetary policy was hardly compatible with any notion of "balanced and sustainable economic growth" (Table 1).

With the advent of inflation targeting, introduced in February 2000 under a new Governor, Tito Mboweni, the constitutional primary objective for monetary policy was formalised through an announced, credible target range for inflation. The exchange rate was deemed to float freely, and mechanisms were instituted for a high level of policy transparency (Table 1). There are no conflicting policy goals under this arrangement. The SARB can accumulate foreign currency reserves and may at times intervene in the market to stabilize short-term fluctuation in the currency. But it cannot under this mandate intervene for long periods to influence the currency in a particular direction without inflationary implications for meeting its target.

Since its adoption, the inflation targeting regime has seen several improvements with evolving institutional design (Table 1), and has significantly raised monetary policy transparency. ${ }^{8}$ Interest rate policy is determined by a Monetary Policy Committee (MPC), in practice by a consensus vote. The process of interest rate setting ${ }^{9}$ can now broadly be described by Svensson's recommended moderate policy of flexible and forward-looking inflation targeting (Svensson et al., 2002), so coping reasonably well with supply shocks. Inflation is not controlled at the shortest possible horizon by aggressive and volatile policy, with often volatile interest rates, but rather at a longer horizon of two to three years. The flexible approach aims also to stabilise the business cycle and hence the output gap. In the short term, inflation may well deviate, and sometimes significantly, from the target. Monetary policy decisions taken in response to sizeable external and domestic shocks under inflation targeting have significantly improved relative to the preceding framework, despite some data constraints (Aron and Muellbauer, 2007a, 2009). In particular, the steady handling of the 2001 exchange rate shock under inflation targeting is contrasted with the costly policy mistakes during the 1998 exchange rate shock. The elimination

\footnotetext{
${ }^{8}$ The regime is evaluated in Aron and Muellbauer (2005, 2007a, 2008, 2009). Other studies describing this regime include Arora (forthcoming); du Plessis (2002, 2003, 2005ab); Mboweni, 1999; and Van der Merwe, 2004).

9 In operational terms, the repurchase or "repo" interest rate is market-determined in tenders of liquidity through repurchase transactions.
} 
by 2004 of the net open forward position ${ }^{10}$ accumulated under previous monetary policy regimes was an important achievement that has reduced sovereign risk. It has allowed the accumulation of foreign exchange reserves for reducing short-term exchange rate instability, and thus inflation and interest rate volatility.

\section{Measuring openness}

Trade openness depends on several factors. These include trade policy via tariffs and non-tariff barriers (including quotas and licences, inspection standards, local content requirements and the like), externally imposed barriers to trade such as trade and financial sanctions, and domestic and external capital controls operating via legislation, taxation or multiple exchange rate regimes. The most important of these is likely to be trade policy. Unfortunately, attempts to measure even the trade policy component of openness are fraught by measurement problems for observable components (such as tariffs), and by the presence of difficult to quantify components of policy (such as quotas and a range of other non-tariff barriers). A comprehensive literature survey of available empirical measures for trade openness in Aron and Muellbauer (2007b) suggests considerable controversy over the validity of trade policy measures used, for instance, in the growth literature.

For SA, there is no index of effective protection combining the effects of surcharges, tariffs and quotas (these last being important in SA trade policy until the mid-1990s). The annual measures of effective protection of Edwards (2005), date only from 1988, too brief a series for robust modelling and forecasting. These measures also do not take account of mismeasured official trade policy, non-tariff barriers, of the effects of sanctions being lifted or a more open access to international finance through a more open capital account.

Our own innovative measure of trade openness overcomes many of the shortcomings of existing measures, and encompasses both observable and unobservable trade policy (details in Aron and Muellbauer, 2007b). The time series measure from 1971 to 2005 is based on modelling the ratio of manufacturing imports to home demand for manufactures, a variable likely to be strongly

${ }^{10}$ The net open foreign currency position (NOFP) refers to the accumulation by the SARB of foreign currency obligations through forward market intervention that were far in excess of its net international foreign currency reserves. At its worst, the NOFP exceeded (minus) US\$23 billion (in 1998), implying a large negative net international reserve position, with substantial costs accruing to the fiscus. 
influenced by trade openness. This is purged of other determinants by including in the model: GDP growth, the terms of trade and the real exchange rate or relative import prices. We measure observable trade policy in the model with trade-weighted tariffs. The unobservable trade policy component (non-tariff barriers and mis-measurement of tariffs) is captured in the model by a smooth, non-linear stochastic trend ${ }^{11}$. Our openness measure is constructed as a weighted combination of known trade policy and the stochastic trend, with weights from the regression coefficients in the model. In application to SA, the shape of the trend is likely also to reflect such factors as the lifting of capital controls and unification of dual exchange rates in the 1990s (as often used in the composite measures above), and the lifting of externally imposed trade sanctions. Our measure thus captures a broader sense of "openness" than is only due to trade policy. It is shown in Figure 1 and corresponds well with the known phases of liberalization.

In practice, when modelling SA inflation, Aron and Muellbauer (2007b) separate the observable trade policy component measure into its sub-components, customs duties, CUSTOM, and temporary surcharges, SURCHARGE, and find the former are significant and the latter are not, probably because of their temporary nature. Moreover, the relative weight on the stochastic trend proxying NTBs differs from that found in the import share equation. Thus, CUSTOM as a long moving average and the stochastic trend proxying NTBs are included separately in our models below.

More conventional measures, real and nominal trade and imported trade volume measures for SA are shown in Figure 2. This nicely illustrates that nominal trade ratios can be misleading where there are large terms of trade shocks, as the value of exports is sensitive to terms of trade fluctuations for primary exporters. The real and nominal import ratios and the real total trade ratios move similarly, and have all risen from the early 1990s. The real ratio rose more with the rand depreciation from the mid-1990s, which depressed imports but had less of an effect on total trade. The growth in real imports since 1990 (and especially 1994), appears to correlate with the removal of the remaining quotas, and the sharp reduction in tariffs from 1994. However, business cycle effects and volatility in the real exchange rate are conflated with these effects, and one cannot interpret individual parts of the graph.

\footnotetext{
${ }^{11}$ In a model that captures known influences on the import ratio, any unexplained variance (apart from white noise error) is then represented by the stochastic trend (estimated using Koopman et al. (2000)).
} 


\section{Exploring the implications of changing openness using the SARB's inflation model}

In this section we demonstrate how the SARB's equation for producer price inflation in its core model, with long-run and short-run homogeneity restrictions, can be improved. By adding a measure for structural change from greater openness, and variables that capture the foreign exchange monetary transmission channel, the fit is better and the model is stable for a decade longer than the SARB model. The new equations are easy to implement and very attractive for policy-makers, as we suggest below. We focus here on the SARB's own equation, using its own choice of variables and its definition of long-run costs (see below). ${ }^{12}$

The SARB models overall producer prices including imports (WPI) as a mark-up over costs, using a weighted combination of unit labour costs for the whole economy (ULC) and import prices (IMPP) to capture the overall costs. They employ a quarterly error correction model for 1990-2005, and the long-run log cost component applies a weight of 27 percent to log import prices, which is its recent weight in the WPI index, and a weight of 73 percent to log unit labour costs. This imposes long-run homogeneity, in that a doubling of unit labour costs and import prices implies that the level of producer prices will also double in the long run. The modelers impose short-run price homogeneity ${ }^{13}$ on the dynamic terms in import prices, unit labour costs and the lagged dependent variable. Figure 3 plots these price data. The only other variable in the model, apart from two dummies, is the output gap, but this enters only in the short-run (i.e. as $\Delta$ GAP). Two dummies capture outliers in 1990q4 and 2002q1.

The model ${ }^{14}$ is shown below:

\footnotetext{
${ }^{12}$ This differs from our previous work, upon which we draw to improve this equation (Aron and Muellbauer, 2007b).

${ }^{13}$ Short-run homogeneity in equation (1) below implies that the sum of the coefficients on the quarterly inflation rates of import prices, unit labour costs and lagged producer prices on the RHS of the equation add up to 1 . This has the implication that doubling these inflation rates would immediately double the inflation rate of producer prices.

${ }^{14}$ The model has a standard error of 0.00678 and an adjusted R-squared of 0.85 and passes the BreuschGodfrey serial correlation test with test statistic 0.11620(4). For details see Smal et al. (2007).
} 


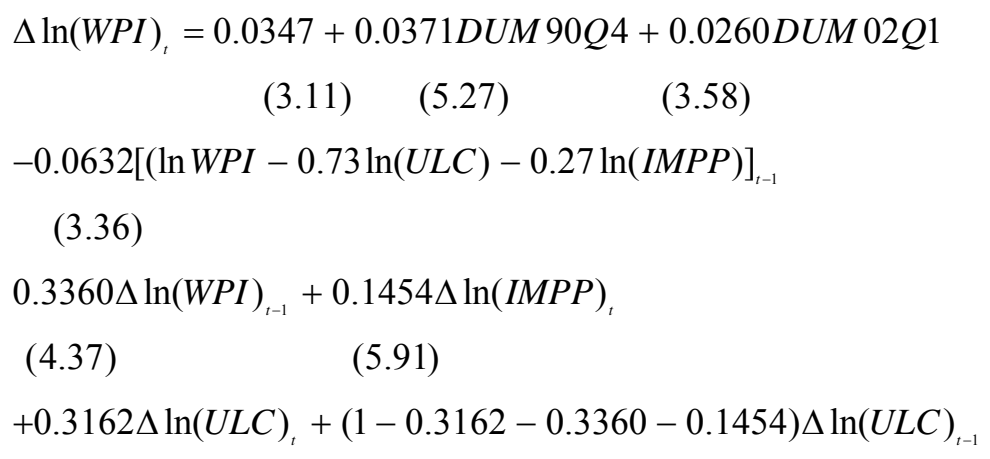

$+0.0059 \Delta(G A P)_{t-1}$

We were able to reproduce this equation from vintage data provided by the Reserve Bank ${ }^{15}$. The data now on the web differ in that post 2000 data have been somewhat revised. However, the vintage data on the producer price index WPI provided by the SARB differ from current data on the web all the way back to the mid 1970s. Figure 4 shows the log ratio of the data currently on the web to the vintage data for 1979 to 2005 : it is clear that the seasonal pattern is quite different, though both series are meant to be seasonally adjusted. By including seasonal dummies, we are able to get results quite close to equation (1) using data available on the web at the end of 2007. Variables are defined with basic statistics in Table 2, and these results are shown in column 1 of Table 3a. The estimated speed of adjustment is now 0.054 compared to the 0.063 shown in equation (1), but the fit and estimated dynamics are very similar.

However, it is desirable to estimate over longer samples than from 1990. Avoiding the period of fixed exchange rates in SA (see Aron et al., 2000), the longest sample would be from after $1979 q 2$, exceeding the SARB model's sample by a decade. When we estimate this model for the longer sample 1980q1 to 2005q4, we find that the speed of adjustment and the significance of the long-run cost component falls sharply, the fit of the model deteriorates and there is first order residual autocorrelation, see column 2. We are able to improve on this model by introducing openness indicators capturing the significant structural change from opening the trade and capital

\footnotetext{
${ }^{15}$ The documentation concerning variables used was insufficiently precise in Smal et al. (2007) to be able to get close without extensive advice. These are the actual variables they used: import prices and unit labour costs are measured using seasonally adjusted series from the National Accounts, respectively as the total imports deflator (SARB codes: KBP6014LK/KBP6014DK) and compensation series (KBP6000LK/KBP6006DK); overall producer prices including imports (KBP7050N); and log real GDP adjusted with a Hodrick Prescott filter for potential GDP (KBP6006DK).
} 
account in stages. Accounting for this important structural shift restores the estimated speed of adjustment and the significance of the long-run cost component, and improves the fit and stability of the model, for 1980 to 2005, see column 3. With an alternative indicator of trade openness defined as the 4 quarter moving average of real exports plus real imports divided by real GDP, all measured in constant prices, we can achieve a similar effect, though with a somewhat worse fit, see column 4.

Imposing short-run homogeneity is not desirable because it fails to account for plausible temporary inflation misperceptions by economic agents. Relaxing the assumption of short-run homogeneity in the longer sample and allowing the dynamics to be estimated freely improves the fit, implying that the hypothesis of short-run homogeneity is rejected, see column 5 (the probability of acceptance is 0.001 ). However, the speed of adjustment is now effectively zero so that the model implies no long run adjustment of producer prices to import prices and unit labour costs. This seems highly implausible, suggesting a possible misspecification because of omitted relevant determinants of whole price inflation.

In Aron and Muellbauer (2007b), we argued that the markup of producer prices on unit labour costs and import prices was likely to be affected by the real exchange rate: the more appreciated the real exchange rate, the greater is likely to be foreign competitive pressure on domestic price setters. We suggested that inflationary expectations were likely to be influenced by the monetary policy stance as reflected in the short term interest rate differential between SA and the world, as proxied by the SA prime rate of interest minus the US Treasury bill rate. Indeed, in Aron et al. (2003), the link is demonstrated between the interest rate differential and the exchange rate, suggesting that the foreign exchange channel is an important link between monetary policy and inflation in SA. In both papers we argued that prices of unprocessed foodstuffs were likely to be an important part of inflation dynamics, in a country where food is a large component in the budgets of the mass of households. We found evidence there that there is a short run asymmetry in the inflation process, in that a rise in the price of food has a larger effect on producer price inflation than a fall (measured as the log change in raw food prices if this is positive and zero if the log change is negative, or ASYMFOOD).

We thus augment the specification shown in column 5 by including the above determinants: the lagged values of the log real exchange rate and its change, the interest rate differential and its change, the current and lagged values of ASYMFOOD, and the level of the lagged output gap. 
We call this the 'simple GUM' (general unrestricted model). Eliminating individually insignificant variables sequentially, or using the Autometrics software (Doornik, 2008), results in the parsimonious model shown in Table $3 \mathrm{~b}$, column 6 . This fits dramatically better than previous specifications shown in Table 3 and supports the claims made by Aron and Muellbauer (2007b). The influence of the long-run cost component is restored, and the real exchange rate, the interest rate spread and (asymmetric) raw food price inflation all have highly significant coefficients. Furthermore, the level of the output gap rather than the change in the output gap is now significant. Parameter stability is highly satisfactory. If the alternative openness measure based on real trade volumes is used, again very similar results but with a slightly worse fit are obtained, see column 7.

There are major advantages for policy-makers from the equations shown in columns 6 or 7 in Table 3b, compared to the SARB's estimated equation. They capture in two ways the important foreign exchange channel, so relevant in open economies, in the transmission from interest rates to inflation: firstly, directly, through the interest rate differential; and secondly, through the real exchange rate, on which monetary policy is generally believed to have influence. Moreover, since the real exchange rate is affected by the terms of trade, the impact of such shocks on inflation is therefore implicit in the model. The important role of food price inflation in the SA inflation process was also confirmed, highly relevant given the record rises in world food prices experienced in 2008. Finally, because the output gap appears as a significant level effect, the model counters a potential criticism often leveled at inflation targeting: that it focuses on inflation at the expense of concerns about stabilizing economic activity. The model clearly indicates a connection between the output gap and inflation. Other things being equal, forward looking inflation targeting policy will therefore tend to raise interest rates to reduce high output gaps (actual log real output minus trend log real output), and lower rates to increase low or negative output gaps. Thus, inflation targeting will tend also to stabilize economic activity.

We also checked the specifications in columns 6 and 7 against an 'extended GUM' in which somewhat longer lags are added to the 'simple GUM' discussed above. These take the form of four-quarter log changes in import prices, unit labour costs, raw food prices, and in last quarter's producer prices, real exchange rate and the interest rate differential (this last not in logs). Furthermore, other lags in the two components of openness are introduced, and a dummy for the introduction of inflation targeting, DUM2000, which is zero up to 1999Q4 and 1 from 2000Q1 
onwards. We also allow detection of outliers in Autometrics, where it adds impulse dummies where outliers exceed 3 times the equation's standard error.

The parsimonious equation now selected, when DUM2000 is forced to be retained ${ }^{16}$, is shown in column 8. Apart from the impulse dummy for 2005Q4 and DUM2000, only one new variable appears: the annual log change in unit labour costs. Given the primacy of unit labour costs in the long run solution, it seems quite plausible to find this additional dynamic role. (Without the outlier correction for 2005Q4, the same specification is chosen, with parameter estimates still very close to those shown in column 8.) The coefficient on DUM2000 is -0.005 and its t-ratio is -2.1. This suggests that inflation targeting may have helped reduce producer price inflation by half a percentage point per annum on top of whatever influence it might have had on the other variables in the model, including unit labour costs, the interest rate differential and the real exchange rate. However, the effect is only marginally significant, and would not have been retained under the automatic model selection run by Autometrics. Again, using the trade volume based measure of openness gives broadly similar results but a slightly worse fit, seen in column 9 . Now DUM2000 is more significant than before, while the 4-quarter change in unit labour costs is now of marginal significance and the $2005 \mathrm{q} 4$ impulse dummy becomes insignificant. The reason for the latter seems to be that this measure of trade openness rose quite sharply in 2005, so helping to explain the low producer price inflation rate in the last quarter.

We test the model for robustness from 1980 over a shorter sample. Interestingly enough, when applying Autometrics, the same model but without DUM2000 and the impulse dummies for $2002 q 1$ and $2005 q 4$, would have been selected for the 1980q1 to $1999 q 4$ sample. These estimates are shown in the final column, column 10.

Three of the right hand side variables shown in the last three columns are potentially endogenous. However, when these are instrumented, using 'intelligent' instrumenting equations based on import price, unit labour cost and food price equations from Aron et al. (2003), the results are hardly affected, apart from a marginal drop in the coefficient for the current inflation rate for imports.

Further evidence in favour of this model for WPI inflation comes from a cointegration analysis (see Johansen (1988) and Johansen and Juselius (1990)), based on the version of the model shown

\footnotetext{
${ }^{16}$ Autometrics gives the option to force a regressor to be in the final model.
} 
in column 9 of Table 3b. Here the openness indicator is based on a moving average of real imports plus exports relative to real GDP. The results of non-stationarity testing were given in Table 2. We consider a set of five endogenous I(1) variables: log WPI, log import prices, $\log$ unit labour costs, log real exchange rate and the interest rate spread. We treat the openness indicator like an exogenous trend, and together with the step dummy, DUM2000, it is treated as part of the cointegration space. The output gap and ASYMFOOD are both $\mathrm{I}(0)$ variables and are treated as weakly exogenous (subsequently tested for). Together with the two impulse dummies, they enter the system in an unrestricted form. We take a lag length of 2 , supported by the data. Thus, the unrestricted VAR consists of five equations in the endogenous variables, with openness, the dummies, ASYMFOOD and the lagged output gap appearing in every equation. Using PCGIVE, we find that the data support a rank of 4 for this system of equations. The following restrictions were imposed on the beta matrix of the system:

a) Four normalising restrictions in the four cointegrating vectors, e.g. a coefficient of 1 on $\log (\mathrm{WPI})$ in the first vector.

b) A restriction of -0.73 and -0.27 on the coefficients respectively of $\log (\mathrm{ULC})$ and $\log (\mathrm{IMPP})$ in the first cointegrating vector (i.e. imposing long-run homogeneity).

c) Three further homogeneity restrictions in the remaining cointegrating vectors, on the logs of WPI, import prices and unit labour costs in each, requiring the sum of their coefficients to add to 0 .

These are acceptable restrictions in terms of a likelihood ratio test. However, with four cointegrating vectors, finding an economic interpretation of each is not straightforward. We successfully tested for the restriction that the alpha coefficients (speeds of adjustment) for the first equation (i.e. for $\log (\mathrm{WPI})$ ) are zero, except for the first cointegrating vector. In other words, we can accept the hypothesis that the other three cointegrating vectors do not appear in an equation for the change in $\log (\mathrm{WPI}) .{ }^{17}$ The p-value for the chi-squared test for the full set of restrictions, including homogeneity is 0.06 . As a final check, we confirmed the weak exogeneity of the output gap and of ASYMFOOD by regressing them on the lagged value of the equilibrium correction

\footnotetext{
${ }^{17}$ To overcome a convergence problem which can arise when restrictions on the beta and alpha coefficients are imposed at the same time, we used a grid method on the $\log ($ REER) coefficient to obtain the optimal values of the parameters. We then find the following cointegrating vector: $(\log$ (WPI) $-0.73 \log$ (ULC)$0.27 \log ($ IMPP $)+0.27 \log ($ REER $)+1.08$ USSPREAD +0.0149 MA4TRVOL $(-1)+0.085$ DUM2000). This is similar to the long-run solution implied by the single equation estimate in Table $3 \mathrm{~b}$, column 9 , though the weight on $\log$ REER is a little lower than in Table 3b. The speed of adjustment, at 0.098, is identical to the single equation estimate. We are grateful to Bent Nielsen for advice on using the grid method.
} 
term implied by the cointegrating vector, and on the I(0) variables appearing in the VAR: the equilibrium correction term proved insignificant in both equations.

Thus, the cointegration analysis confirms the key findings of the single equation model for producer price inflation. However, it does suggest that instrumenting current import price inflation in single equation modeling is desirable, given the endogeneity of import prices.

\section{Conclusion}

We have outlined the changing openness of the SA economy particularly since the early $1990 \mathrm{~s}$, with the liberalisation of the trade and capital accounts, and the greater acceptability of SA as a trading partner and investment destination under a new democratic government since 1994. Systematic risk was lowered by the post-1994 political dispensation, by the fiscal policies adopted since 1994 and by monetary policies, primarily since 1999. Conducting monetary policy with outdated monetary targets and without clear policy priorities and policy transparency in a more globalised economy between 1994 and 1999 saw large fiscal losses and highly volatile interest rate policy during mismanaged currency crises, particularly in 1998. This led to the adoption of a more transparent and effective regime of inflation targeting from 2000. The fiscalmonetary policy mix has stabilised the macro-economy, lowering sovereign risk, uncertainty and the real (tax-adjusted) user cost of capital.

We have argued that modeling and forecasting inflation, a key ingredient of policy making under inflation targeting, needs to take account of the structural break due to changing openness, in order to produce stable and well-fitting models over longer samples. We have demonstrated the improvements when including our indicators for openness (and, indeed, even a conventional openness indicator) in the SARB's own inflation model for wholesale price inflation. We also confirmed the strong influence on producer price inflation, found in our earlier work, of the real exchange rate and the interest rate differential. This makes explicit the foreign exchange channel of monetary transmission on inflation, important in open economies. The role of food price inflation in the SA inflation process was also confirmed. This is highly relevant at the time of writing, given the record rises in world food prices experienced in 2008. The result is a model for producer price inflation with a greatly improved fit and stability over longer samples, and a role for the level of the output gap rather than simply a short-run effect, as in the SARB's model. This 
helps mitigate the arguments against inflation targeting regarding its apparent unconcern for stabilizing output. Given the important role for the output gap in the inflation model, inflation targeting automatically tends to stabilise output also. Finally, it is worth noting the easy to implement and constructive nature of our improvements to the SARB producer price inflation model: essentially we add five new regressors to their model and relax a restriction on the shortterm dynamics.

The technique we have used to capture increased openness is potentially of use to other emerging market countries. In the case of SA, we also showed that a cruder measure of trade openness based on real import plus export volumes relative to real GDP, does almost as well in the inflation model as our more sophisticated measures. It seems that this volume measure compensates quite well for real exchange rate and terms of trade shocks which are liable to bias measures based on nominal data or on import data alone (see section 3).

Many analysts believe that the use of inflation targeting will spread. This makes it even more important for economists to develop a better understanding of the determinants of inflation in the short and medium run in increasingly open economies. Failing to do so may lead central bank modellers to forecast from misspecified models that omit the structural breaks of past trade liberalisation, and may lead to the choice of inappropriate monetary policy.

\section{References}

Aron, J. and I. Elbadawi. 1999. "Reflections on the South African Rand Crisis of 1996 and its Consequences." WPS/1999-13. Centre for the Study of African Economies, Oxford University.

Aron, Janine, Ibrahim Elbadawi, and Brian Kahn. 2000. "Real and Monetary Determinants of the Real Exchange Rate in South Africa." In Development Issues in South Africa, edited by Ibrahim Elbadawi and Trudy Hartzenberg. London: MacMillan.

Aron, J., B. Kahn and G. Kingdon (eds.) South African Economic Policy Under Democracy, Oxford University Press (forthcoming, March, 2009).

Aron, J. and J. Muellbauer. 2009. "The Development of Transparent and Effective Monetary and Exchange Rate Policy." Chapter 3 in Aron, J., B. Kahn and G. Kingdon (eds.) South African Economic Policy Under Democracy, Oxford University Press (forthcoming, March, 2009).

Aron, J. and J. Muellbauer. 2008. "The predictability of South Africa's monetary policy with enhanced transparency under inflation targeting." Centre for Economic Policy Research (CEPR), London, Working Paper (forthcoming). 
Aron, J. and J. Muellbauer. 2007a. "Review of Monetary Policy in South Africa since 1994." in Aron, J. and G. Kingdon. (eds.), Special issue on "South African Economic Policy under Democracy", Journal of African Economies, Oxford University Press 16 (5): 705-744.

Aron, J. and J. Muellbauer. 2007b. "Inflation dynamics and trade openness." Centre for Economic Policy Research, London, Working Paper Series no. 6346, 2007. (http://www.cepr.org).

Aron, J and J. Muellbauer. 2005. "Monetary policy, macro-stability and growth: South Africa's recent experience and lessons." World Economics: 6(4): 123-147.

Aron, J. and J. Muellbauer. 2002a. "Interest rate effects on output: evidence from a GDP forecasting model for South Africa." IMF Staff Papers 49 (IMF Annual Research Conference): $185-213$.

Aron, J. and J. Muellbauer. 2002b. "Estimating Monetary Policy Rules for South Africa", in Norman Loayza and Klaus Schmidt-Hebbel (eds) "Monetary Policy: Rules and Transmission Mechanisms", Series on Central Banking, Analysis and Economic Policies, Volume 4, Central Bank of Chile, pages 427-475. (http://www.bcentral.cl/eng/studies/central-banking/v4.htm)

Aron, J., J. Muellbauer and B. Smit. 2003. "Understanding the Inflation Process in South Africa." Keynote Address, Eight Annual Conference on Econometric Modelling for Africa, Stellenbosch University, South Africa, July. (http://www.csae.ox.ac.uk/, "The SA Macroeconomic Research Programme").

Arora, V. 2008. "Monetary Policy Transparency and Financial Market Forecasts in South Africa." Journal of Economic and Financial Sciences 2(1) (forthcoming).

de Kock, G., 1978, Commission of Inquiry into the Monetary System and Monetary Policy in South Africa, Interim Report (Pretoria: Government Printer).

de Kock, G., 1985, Commission of Inquiry into the Monetary System and Monetary Policy in South Africa, Final Report (Pretoria: Government Printer).

Doornik, J.A. 2008. "Autometrics.” in J. L. Castle and N. Shephard (eds.), Festschrift in Honour of David F. Hendry, Oxford University Press (forthcoming).

du Plessis, S. A. 2002. "Evaluating the SARB's inflation target." South African Journal of Economics 70(6): 982-1007

du Plessis, S. A. 2003. "Much Ado About Nothing: A Note on the Modified Inflation Target, South African Journal of Economics 71 (2): 407-413

du Plessis, S. A. 2005a. "The democratic deficit and inflation targeting." South African Journal of Economics 73(1): 93-104.

du Plessis, S. A. 2005b. "Proposals for strengthening the SARB's inflation targeting regime." South African Journal of Economics 73(2): 337-354.

Edwards, Lawrence, 2005. "Has South Africa liberalised its trade?" South African Journal of Economics, 73:4 (2005), 754-775.

Edwards, L., R. Cassim and D. E. van Seventer. 2009. "Trade Policy since Democracy ." in Aron, J., B. Kahn and G. Kingdon (eds.) South African Economic Policy Under Democracy, Oxford University Press (forthcoming, March, 2009).

Gidlow, R.M. 1995a. South African Reserve Bank Monetary Policies under Dr. T.W. de Jongh, 1967-80. The South African Reserve Bank.

Gidlow, R.M. 1995b. South African Reserve Bank Monetary Policies under Dr. Gerhard de Kock, 1981-89. The South African Reserve Bank.

Hirsch, A. 2005. Season of Hope: Economic Reform under Mandela and Mbeki. IDRC, KZN Press. 
Johansen, S. 1988. "Statistical analysis of cointegration vectors." Journal of Economic Dynamics and Control 12: 231-54.

Johansen, S. and K. Juselius. 1990. "Maximum Likelihood Estimation and Inference on Cointegration - with Applications to the Demand for Money." Oxford Bulletin of Economics and Statistics 52 (2): 169-210.

Kahn, B. and J. Leape. 1996. "Managing the Rand's depreciation: The role of intervention." Quarterly Review, Centre for Research into Economics and Finance in Southern Africa, London School of Economics, April.

Koopman Siem J., Andrew C. Harvey, Jurgen A. Doornik, and Neil Shephard, STAMP: Structural Time Series Analyser, Modeller and Predictor (London: Timberlake Consultants Press, 2000)).

Leape, J. and L. Thomas. 2009. "Capital flows and the External Balance Sheet ." in Aron, J., B. Kahn and G. Kingdon (eds.) South African Economic Policy Under Democracy, Oxford University Press (forthcoming, March, 2009).

Mboweni, T.T. 1999. "Inflation Targeting in South Africa." South African Journal of Economics 67 (4): 221-225, December.

Nowak, N. and L. Ricci (eds.) Post-Apartheid South Africa, International Monetary Fund.

Obstfeld, M. 1996. "Models of currency Crises with Self-fulfilling Features", European Economic Review 40: 1037-1047.

Smal, M. M., C. Pretorius and N. Ehlers. 2007. "The core forecasting model of the South African Reserve Bank.” Working Paper WP/07/02, June.

South African Reserve Bank. 2000. A New Monetary Policy Framework: Appendix, Statement of the Monetary Policy Committee. Pretoria (April 6).

Stals, C. 1995. "Monetary Policy in South Africa." Address to the Second South African Economy, Investment and Trade Conference, London, October 17.

Stals, C. 1997. "Effect of the changing financial environment on monetary policy in South Africa." Address to the Annual Dinner of the Economic Society of South Africa, Pretoria Branch, 15 May.

Sterne, Gabriel and Jonathan Lepper. 2002 "Parliamentary Scrutiny of Central Banks in the United Kingdom and Overseas." Bank of England Quarterly Bulletin, Autumn.

Svensson, L, K. Houg, A. Berg, H. Solheim and E. Steigum. 2002. "An Independent Review of Monetary Policy and Institutions in Norway." September. Norges Bank Watch. Centre for Monetary Economics, BI Norwegian School of Management.

Taylor, J. 1993. "Discretion versus Policy Rules in Practice." Carnegie-Rochester Conference on Public Policy 39: 195-214.

Van der Merwe, E. 2004. "Inflation targeting in South Africa." Occasional Paper No. 19, July, South African Reserve Bank. 
Figure 1: Openness measure and stochastic trend, plus the tariff ratios for South Africa
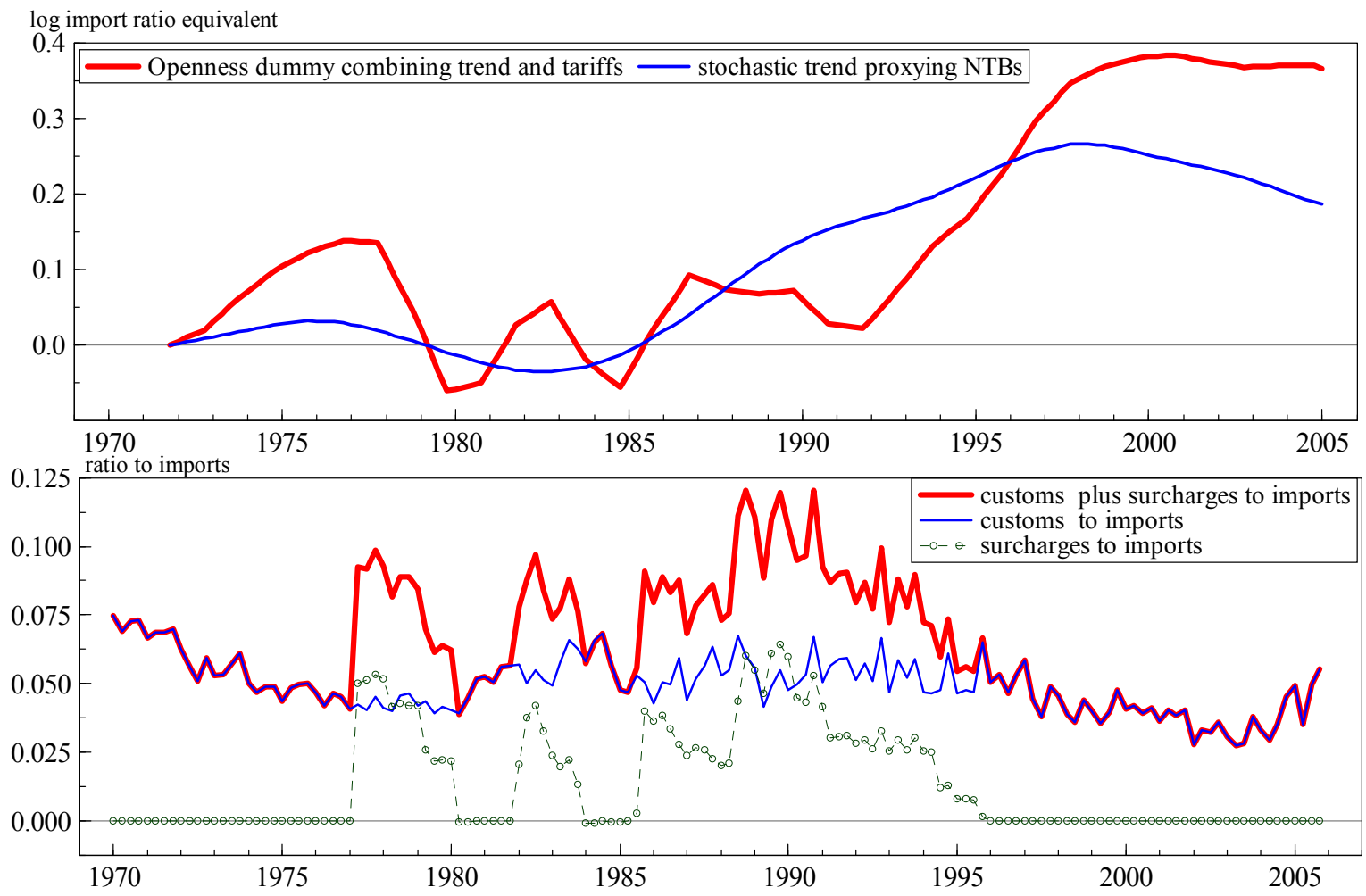

Source: SARB Quarterly Bulletin and Aron and Muellbauer (2007b) 
Figure 2: Real and nominal trade and imported trade volume measures for SA

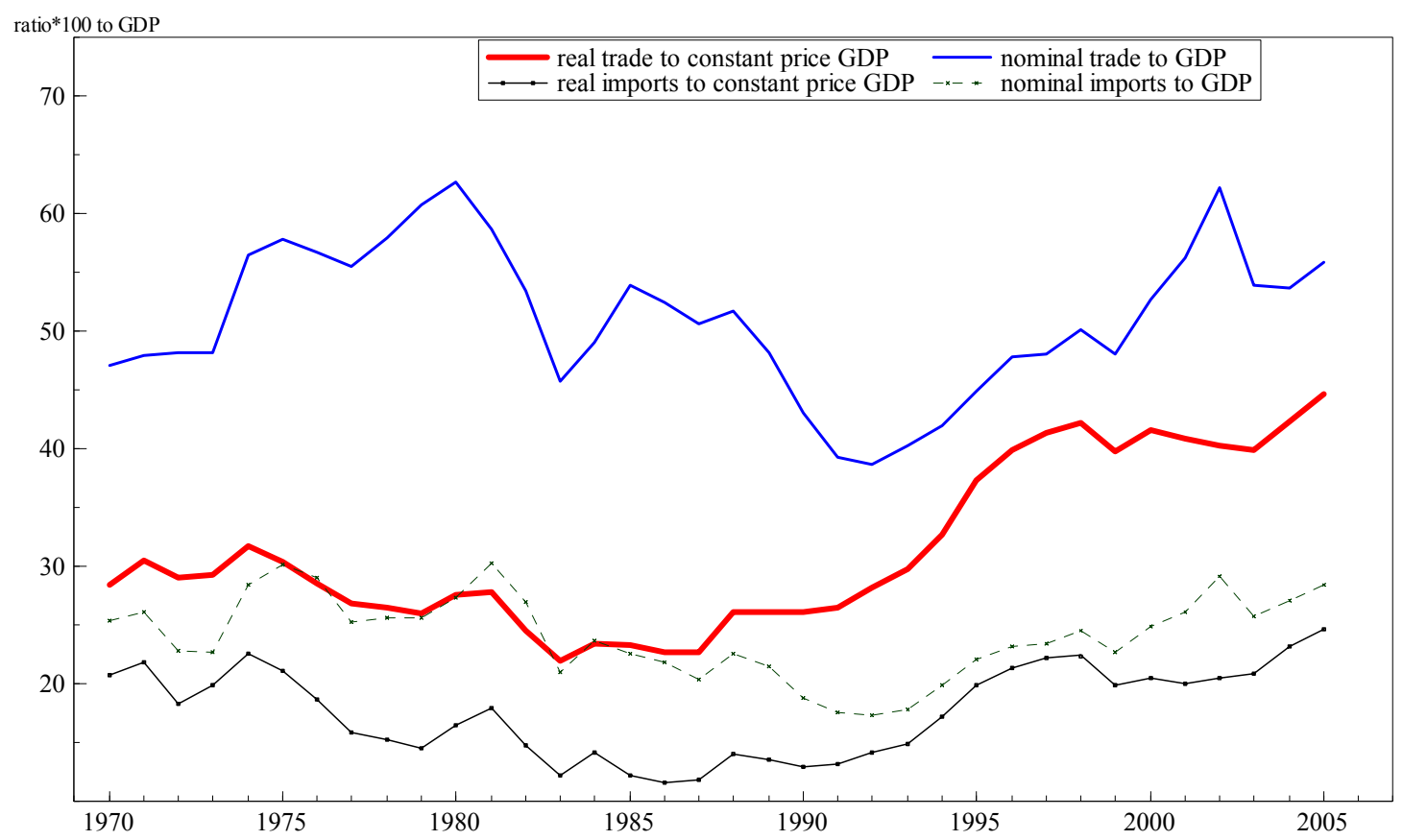

Source: SARB Quarterly Bulletin

Figure 3: Log changes in wholesale and import prices and unit labour costs

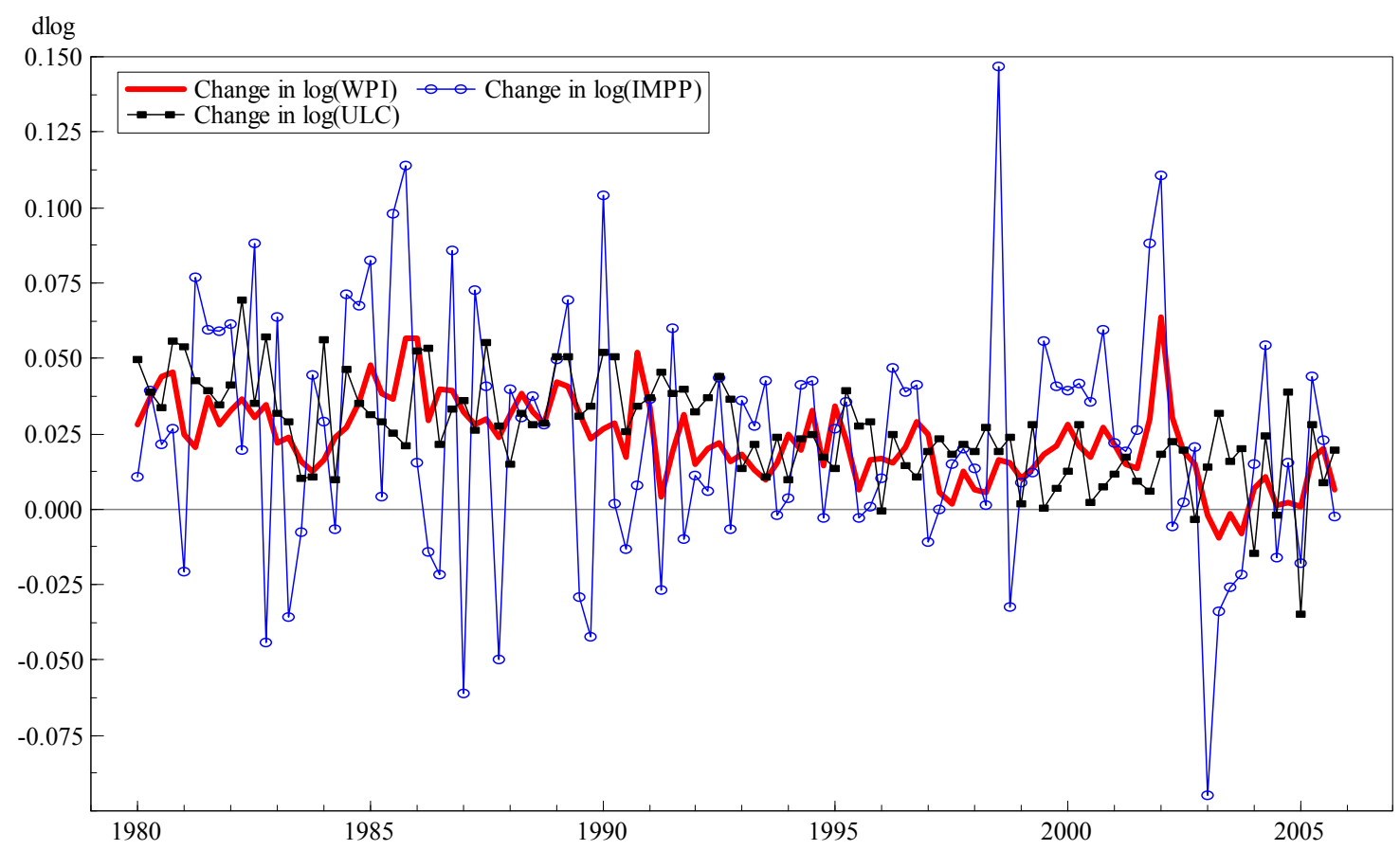

Source: SARB Quarterly Bulletin (definitions in Table 3) 
Figure 4: Log ratio of current WPI data to the vintage data used in the SARB's model

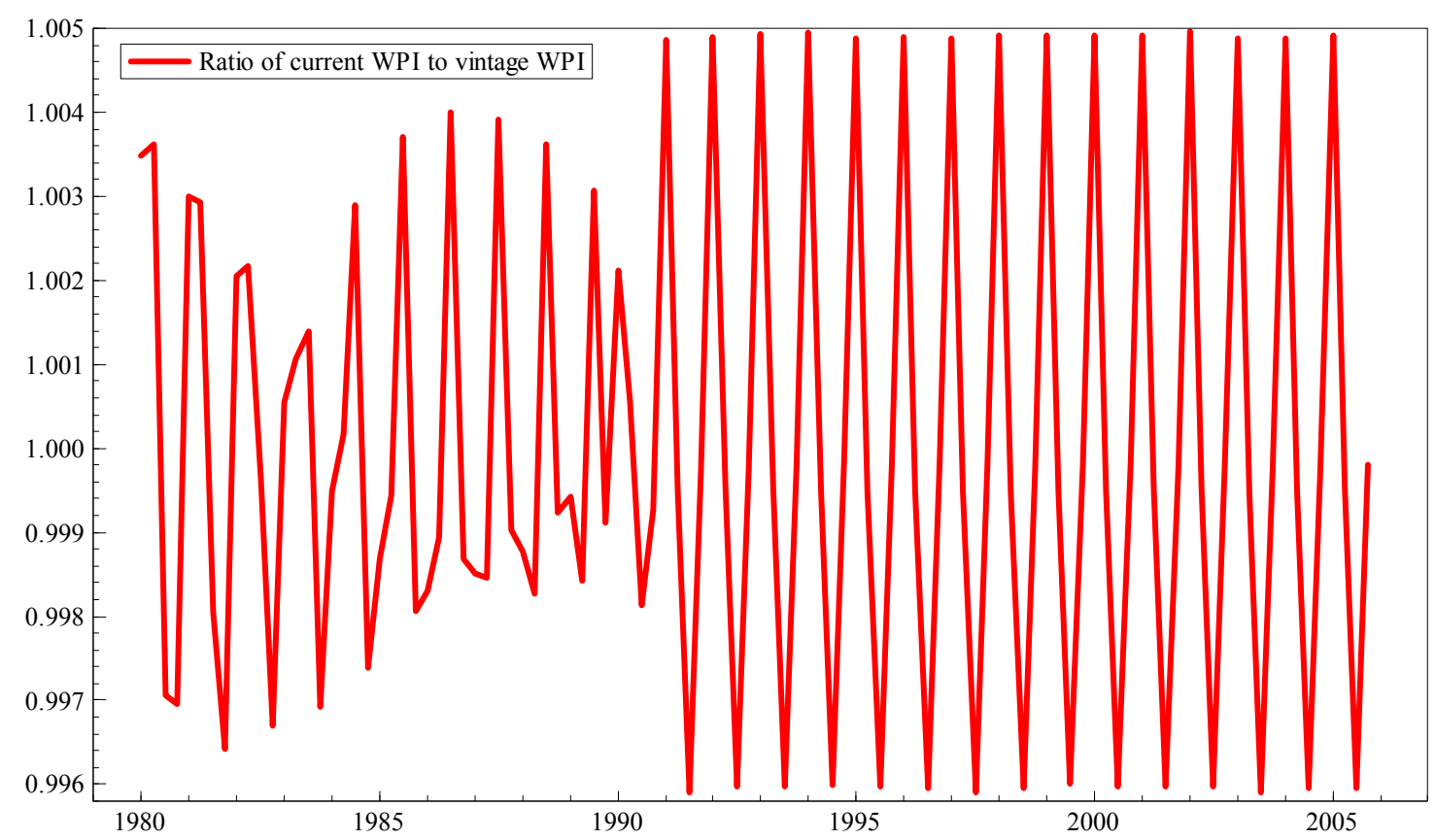


Table 1: Comparative design, transparency and accountability features of monetary regimes from 1990

\begin{tabular}{|c|c|c|}
\hline Characteristics & $\begin{array}{l}\text { Money targeting regime under Governor Stals } \\
1986-1998 \text { (Stals' term began in 1989:2) }\end{array}$ & $\begin{array}{l}\text { Inflation targeting regime under Governor Mboweni } \\
2000 q 1 \text { onwards (Mboweni's term began in 1999:3) }\end{array}$ \\
\hline $\begin{array}{l}\text { Objective(s) and explicit } \\
\text { prioritization of monetary } \\
\text { policy }\end{array}$ & $\begin{array}{l}\text { Objective } \\
\text { Under Stals, an initial mission statement, published in 1990, } \\
\text { entrusted the protection of the domestic and external value of } \\
\text { the Rand to the Bank. This was carried through to the Interim } \\
\text { Constitution (late April, 1994): "The primary objectives of the } \\
\text { South African Reserve Bank shall be to protect the internal } \\
\text { and external value of the currency in the interest of balanced } \\
\text { and sustainable economic growth in the Republic." } \\
\text { Priority } \\
\text { This can be interpreted as having both a price and an exchange } \\
\text { rate target in mind, without explicit prioritisation. } \\
\text { The objective was clarified in late } 1996 \text { - see next column. }\end{array}$ & $\begin{array}{l}\text { Objective } \\
\text { The Constitution Act of the Republic of South Africa, No } 8 \text { of } 1996 \text { (section 224) and the } \\
\text { amended South African Reserve Bank Act, No } 90 \text { of } 1989 \text { (section } 3 \text { substituted by section } 2 \\
\text { of Act } 2 \text { of 1996): "The primary objective of monetary policy is to protect the value of the } \\
\text { currency in order to obtain balanced and sustainable economic growth in the country." } \\
\text { Priority } \\
\text { Appendix to the Statement of the Monetary Policy Committee (MPC) - } 6 \text { April 2000: "A } \\
\text { New Monetary Policy Framework", Statement issued by Mr. T.T. Mboweni, Governor of the } \\
\text { SARB: "It requires the achievement of financial stability, i.e. price stability as well as stable } \\
\text { conditions in the financial sector as a whole." "The new inflation-targeting monetary policy } \\
\text { framework is primarily concerned with one element of financial stability, i.e. price stability." }\end{array}$ \\
\hline $\begin{array}{l}\text { Appointment and tenure of } \\
\text { Governor }\end{array}$ & \multicolumn{2}{|c|}{$\begin{array}{l}\text { The President of South Africa appoints the Governor and three deputy governors for terms of five years, after consultation with the Minister of Finance and } \\
\text { the Board. Parliament does not have the power to veto the appointment of the Governor. The Finance Minister may dismiss governors but, under current law, } \\
\text { only for malfeasance or incapacity. }\end{array}$} \\
\hline $\begin{array}{l}\text { Accou } \\
\text { parlia }\end{array}$ & \multicolumn{2}{|c|}{$\begin{array}{l}\text { The number of appearances before Parliament, made by central bank officials is decided by statute and the parliamentary committee. }{ }^{\mathrm{A}} \text { The objective is to } \\
\text { account for monetary policy decisions. Parliamentary scrutiny of the SARB is provided for in the Reserve Bank Act. Monthly statements of assets and } \\
\text { liabilities, annual financial statements and an audit report have to be submitted to the Department of Finance, that later are tabled in Parliament by the Minister } \\
\text { of Finance (Section 32). The Governor is also required by the Act to submit an annual report to the Minister on the implementation of monetary policy. } \\
\text { Periodically, the Governor and senior staff appear before the Parliamentary Portfolio Standing Committee on Finance to account for monetary policy (now } \\
\text { televised). In SA under the Reserve Bank Act, the Ministry of Finance has recourse to the Supreme Court should it judge the SARB as having deviated from } \\
\text { its mandate, where it has not appropriately responded to written instructions to rectify matters from the Ministry (Section 37). }\end{array}$} \\
\hline $\begin{array}{l}\text { Accountability to share- } \\
\text { holders }\end{array}$ & \multicolumn{2}{|c|}{$\begin{array}{l}\text { The Reserve Bank is unusual in being one of only three central banks that is still privately-owned. The SARB is internally governed by a board of } 14 \text { directors, } \\
\text { seven appointed by the President (of whom one is the Governor and three are Deputy-Governors) and seven by public share-holders. The Annual Report and } \\
\text { accounts are approved by shareholders in annual meetings. The South African Reserve Bank Act stipulates conditions for tenure of Bank directors (including } \\
\text { the Bank's governor), but it does not explicitly give criteria for the removal of directors from office. The Minister of Finance has powers of regulation in } \\
\text { relation to good governance by the board (Section 35). }\end{array}$} \\
\hline $\begin{array}{l}\text { Explicit contract between } \\
\text { the monetary authorities } \\
\text { and the government }\end{array}$ & $\begin{array}{l}\text { Operational responsibility was described by the South African } \\
\text { Reserve Bank Act (No } 90 \text { of 1989). But before the Interim } \\
\text { Constitution was adopted there were no explicit arrangements } \\
\text { or contracts between the government and the SARB on } \\
\text { instrument independence. The Interim Constitution (Act 200, } \\
\text { 1993, assented to on } 25 \text { January, 1994, commencing on } 27 \\
\text { April, 1994) states it shall perform its functions independently. }\end{array}$ & $\begin{array}{l}\text { Constitutional independence of the SARB was enacted in 1996: Section } 224 \text { (2) of the } \\
\text { Constitution states: "The SARB, in pursuit of its primary object must perform its functions } \\
\text { independently and without fear, favour or prejudice, but there must be regular consultation } \\
\text { between the Bank and the Cabinet member responsible for national financial matters." } \\
\text { Operational independence was achieved initially through an exchange of letters between } \\
\text { government and Bank. }\end{array}$ \\
\hline Nature of target & $\begin{array}{l}\text { Rate of increase in M3: a broad definition of money including } \\
\text { notes and coins held by the public and all types of deposits of } \\
\text { the domestic private sector with domestic banking institutions. }\end{array}$ & $\begin{array}{l}\text { Rate of increase in CPIX: the overall consumer price index, excluding the mortgage interest } \\
\text { cost. }\end{array}$ \\
\hline Setting of the target & $\begin{array}{l}\text { Set by the National Treasury after consultation with the } \\
\text { SARB. }\end{array}$ & ed by the Cabinet. \\
\hline
\end{tabular}




\begin{tabular}{|c|c|c|}
\hline Characteristics & $\begin{array}{l}\text { Money targeting regime under Governor Stals } \\
1986-1998 \text { (Stals' term began in 1989:2) }\end{array}$ & $\begin{array}{l}\text { Inflation targeting regime under Governor Mboweni } \\
\text { 2000q1 onwards (Mboweni's term began in 1999:3) }\end{array}$ \\
\hline Range and horizon of target & $\begin{array}{l}\text { Annual target ranges were set using a three-month moving } \\
\text { average of broad money growth (M3), and announced in the } \\
\text { March Budget to cover the year from the preceding fourth } \\
\text { quarter to the current fourth quarter. See all upper and lower } \\
\text { bounds in Figure } 1 .\end{array}$ & $\begin{array}{l}\text { The inflation target announced in February, 2000, was specified as an average rate of } \\
\text { increase in CPIX of 3-6 percent per annum for the calendar year 2002. This was revised in } \\
\text { October, } 2001 \text { to } 3-6 \text { percent for } 2003 \text { and 3-5 percent for } 2004 \text { and 2005; in October } 2002 \text {, } \\
\text { to 3-6 percent for } 2004 \text { and 3-5 percent for 2005; and in February, 2003, the target range for } \\
2005 \text { was increased from 3-5 percent to 3-6 percent. Currently, the inflation target aims to } \\
\text { achieve a rate of increase of in CPIX of between } 3 \text { and } 6 \text { percent per year. The unfortunate } \\
\text { requirement that CPIX be within the target range on average over the calendar year was } \\
\text { altered only in November, 2003, to a continuous target of 3-6 percent beyond } 2006 \text {. }\end{array}$ \\
\hline $\begin{array}{l}\text { Breach of target/escape } \\
\text { clause/explanation clause }\end{array}$ & $\begin{array}{l}\text { There was discretion without penalty to breach targets, for } \\
\text { instance in the face of external trade and financial shocks, but } \\
\text { there was no formally required public explanation (Gidlow, } \\
\text { 1995ab). }\end{array}$ & $\begin{array}{l}\text { A letter to the Governor from the Minister of Finance at the inception of inflation targeting } \\
\text { (released in June, 2001), contained an "escape clause"; there was an "escape clause" in the } \\
\text { inflation targeting statement in the appendix to the MPC statement, April 6, 2000; and a } \\
\text { clause in the Medium Term Budget Policy Statement, October, 2001. Detailed statements } \\
\text { can be found in Aron and Muellbauer (2007a). In November, 2003, the SARB in } \\
\text { consultation with the National Treasury revised earlier clauses for more flexibility and } \\
\text { clarity, into a forward-looking "explanation clause" (Medium Term Budget Policy } \\
\text { Statement, November 2003): "When the economy is buffeted by a supply side shock similar } \\
\text { to those envisaged by the original escape clause that will take inflation outside the target } \\
\text { range (e.g. an oil price shock, a drought, a natural disaster, or financial contagion affecting } \\
\text { the currency), at the subsequent meeting of the Monetary Policy Committee, the SARB will } \\
\text { fully inform the public of the nature of the "shock', the anticipated impact on CPIX inflation } \\
\text { and the monetary policy response to ensure that inflation returns to the target and the time } \\
\text { frame over which this will occur." (Medium Term Budget Policy Statement, November } \\
\text { 2003). }\end{array}$ \\
\hline $\begin{array}{l}\text { Explicit policy rule or } \\
\text { strategy in monetary policy } \\
\text { framework }\end{array}$ & $\begin{array}{l}\text { In } 1994 \text { under Stals, the monetary policy targets had given } \\
\text { way to a range of indicators (Quarterly Bulletin, October, } \\
\text { 1997). There was no explicit rule and policy was opaque (see } \\
\text { Aron and Muellbauer, 2002b). }\end{array}$ & $\begin{array}{l}\text { Inflation targeting with an explicit target was adopted in 2000, see Appendix to the } \\
\text { Statement of the Monetary Policy Committee - } 6 \text { April 2000: "A New Monetary Policy } \\
\text { Framework", Statement issued by Mr. T.T. Mboweni, Governor, SARB. }\end{array}$ \\
\hline MPC and meetings & $\begin{array}{l}\text { By the South African Reserve Bank Act (No } 90 \text { of 1989, and } \\
\text { subsequent amendments), only the governor and deputy } \\
\text { governors can vote on monetary policy matters. Dates of } \\
\text { meetings were not publicised. The Minister of Finance could } \\
\text { also be consulted, but policy could be altered without the } \\
\text { minister's approval, and minutes of the minister's meetings } \\
\text { with the SARB were not published. There was no MPC: } \\
\text { decisions were made by the Governor, after consultation with } \\
\text { the deputy governors (see section 1.3). }\end{array}$ & $\begin{array}{l}\text { Interest rate decisions are reached by the Monetary Policy Committee (initially } 15 \text { and now } 9 \\
\text { members). By the South African Reserve Bank Act (No } 90 \text { of } 1989 \text {, and subsequent } \\
\text { amendments), only the governor and deputy governors can vote on monetary policy matters; } \\
\text { however, in practice, decisions are made by 'consensus'. Since late } 1999 \text {, the Governor } \\
\text { appoints members to the MPC (there is no provision in the Reserve Bank Act for the } \\
\text { composition of the Committee). The MPC has no external members. The structure of the } \\
\text { MPC has changed since its formation in October, 1999, as have the frequency of its } \\
\text { meetings. In 2007, it comprised } 7 \text { SARB officials, chaired by the governor, and meeting six } \\
\text { times per year as of 2004. Dates of meetings are published in advance on the website. }\end{array}$ \\
\hline Minutes of meetings & Minutes of these meetings were not published & Minutes of these meetings are not published. \\
\hline Voting records & No voting records. & No voting is carried out in the MPC. \\
\hline $\begin{array}{l}\text { Announcement of policy } \\
\text { decisions }\end{array}$ & $\begin{array}{l}\text { There were sometimes press announcements about rate } \\
\text { changes, but not every time the rate changed. }\end{array}$ & $\begin{array}{l}\text { Policy decision changes are currently announced on the last day of the three day MPC } \\
\text { meeting, at } 3 \text { p.m.. There is a press release and the announcement is televised. }\end{array}$ \\
\hline
\end{tabular}




\begin{tabular}{|c|c|c|}
\hline Characteristics & $\begin{array}{l}\text { Money targeting regime under Governor Stals } \\
1986-1998 \text { (Stals' term began in 1989:2) }\end{array}$ & $\begin{array}{l}\text { Inflation targeting regime under Governor Mboweni } \\
\text { 2000q1 onwards (Mboweni's term began in 1999:3) }\end{array}$ \\
\hline $\begin{array}{l}\text { Explanation of policy } \\
\text { decisions }\end{array}$ & $\begin{array}{l}\text { Explanations were given on those occasions when there were } \\
\text { press statements. There were no announcements or } \\
\text { explanations when it was decided to maintain interest rates. }\end{array}$ & $\begin{array}{l}\text { An explanation is given in the MPC statement directly after every MPC meeting, both when } \\
\text { interest rates change and when they do not. }\end{array}$ \\
\hline $\begin{array}{l}\text { Explicit policy inclination } \\
\text { after policy meetings }\end{array}$ & $\begin{array}{l}\text { Explicit inclinations were not given after every announcement } \\
\text { of interest rate changes. }\end{array}$ & $\begin{array}{l}\text { There is currently no explicit policy inclination after policy meetings, though the statement } \\
\text { as of about two years ago refers to the MPC's perception of the balance of risks with respect } \\
\text { to the forecast. }\end{array}$ \\
\hline $\begin{array}{l}\text { Publication of } \\
\text { macroeconomic model used } \\
\text { for policy analysis }\end{array}$ & $\begin{array}{l}\text { Prior to inflation targeting, various Quarterly Bulletin articles } \\
\text { revealed parts of the SARB's large (400-equation) model, but } \\
\text { it was never published as a whole. }\end{array}$ & $\begin{array}{l}\text { The SARB model has been reconstructed since about } 1999 \text { with assistance from the Bank of } \\
\text { England and others. It is still under development, and one working paper has been published } \\
\text { with the core model. The actual series employed in the equations are not given (e.g. see } \\
\text { section } 5 \text { of this paper). }\end{array}$ \\
\hline $\begin{array}{l}\text { Publication of } \\
\text { macroeconomic forecasts }\end{array}$ & No forecasts were published in the Stals era. & $\begin{array}{l}\text { The Monetary Policy Review is published twice annually (see website), and contains an } \\
\text { inflation forecast up to } 2 \text { years ahead in the form of a fan chart. No detail is given on the } \\
\text { underlying assumptions, except that the repo rate is assumed unchanged for the forecast } \\
\text { period. There are no forecasts for output. }\end{array}$ \\
\hline Evaluation of forecasts & $\begin{array}{l}\text { There was a quarterly analysis of current macro-economic } \\
\text { developments and disturbances in the Quarterly Bulletin, but } \\
\text { no forecasts were published. }\end{array}$ & $\begin{array}{l}\text { There is a quarterly analysis of current macro-economic developments and disturbances in } \\
\text { the Quarterly Bulletin. The forecast errors up to } 2005 \text { were discussed in a recent SARB } \\
\text { working paper, but they are not annually evaluated. }\end{array}$ \\
\hline $\begin{array}{l}\text { Evaluation of policy } \\
\text { operating targets }\end{array}$ & $\begin{array}{l}\text { The main operating instrument in } 1994 \text { was the bank rate. } \\
\text { There are no data, graphical or other evaluation of the control } \\
\text { of the operating target. But control over the operating target } \\
\text { was nearly perfect. }\end{array}$ & $\begin{array}{l}\text { The main operating instrument in } 2007 \text { is the repurchase or "repo" interest rate, market- } \\
\text { determined in tenders of liquidity through repurchase transactions. There are no data, } \\
\text { graphical or other evaluation of the control of the operating target. But control over the } \\
\text { operating target has been nearly perfect. }\end{array}$ \\
\hline $\begin{array}{l}\text { Evaluation of the policy } \\
\text { outcome given } \\
\text { macroeconomic objectives }\end{array}$ & $\begin{array}{l}\text { Governor Stals gave extensive speeches and explanations, } \\
\text { which were available on the web (no longer) which covered } \\
\text { aspects of discrepancies between the policy outcome and } \\
\text { target. }\end{array}$ & $\begin{array}{l}\text { The Monetary Policy Review discusses discrepancies between the policy outcome and the } \\
\text { target. }\end{array}$ \\
\hline
\end{tabular}

Sources: Aron and Muellbauer (2002b, 2007ab), Gidlow (1995ab).

Notes: A. Concerning parliamentary accountability and applying the survey of Sterne and Lepper (2002), there were 3 parliamentary hearings in 2006, all attended by the Governor, with 1 or 2 officials, relating to anything published in the Quarterly Bulletin. Currently there are 13 members of the Portfolio Committee on Finance; on average 10 members attend and 8 members have academic training (at different levels). There are 2 full-time staff members. The committee receives no technical or analytical support, and has no part-time external advisors. One-off briefings are sometimes given to the committee on chosen topics by external economists, though after the address of the Governor to the Committee. 
Table 2. Variable definitions for parsimonious equations

\begin{tabular}{|c|c|c|c|c|c|}
\hline Variable name & Variable definition & Mean & $\begin{array}{l}\text { Standard } \\
\text { deviation }\end{array}$ & $\mathbf{I}(\mathbf{1})^{\mathrm{a}, \mathrm{b}}$ & $\mathbf{I}(2)^{\mathrm{a}, \mathrm{b}}$ \\
\hline $\log (\mathrm{WPI})$ & $\begin{array}{l}\text { Log of overall producer price index } \\
\text { including imports. }\end{array}$ & -0.665 & 0.715 & -2.61 & $-3.83^{*}$ \\
\hline $\log (\mathrm{ULC})$ & $\begin{array}{l}\text { Unit labour costs measured as: log of } \\
\text { National Accounts compensation deflator }\end{array}$ & -1.52 & 0.814 & -0.0513 & $-11.7 * *$ \\
\hline $\log (\mathrm{IMPP})$ & $\begin{array}{l}\text { Import prices measured as: log of National } \\
\text { Accounts total imports deflator. }\end{array}$ & -0.739 & 0.718 & -1.75 & $-10.9^{* *}$ \\
\hline $\begin{array}{l}(\log (\text { WPI })- \\
0.73 \log (\mathrm{ULC})- \\
0.27 \log (\mathrm{IMPP})\end{array}$ & $\begin{array}{l}\text { The SARB model's long-run cost } \\
\text { component measured as: log (WPI) minus } \\
\text { the weighted sum of unit labour costs, ULC, } \\
\text { and the import price, IMPP. }\end{array}$ & 0.643 & 0.0793 & -1.84 & $-3.98 * *$ \\
\hline $\log ($ REER $)$ & $\begin{array}{l}\text { Log of real effective exchange rate. A rise is } \\
\text { appreciation. }\end{array}$ & 4.75 & 0.148 & -3.22 & $-4.87 * *$ \\
\hline USSPREAD & $\begin{array}{l}\text { Spread between the SA prime rate and US } \\
\text { government Treasury Bill rate. }\end{array}$ & 0.108 & 0.0466 & $-3.39^{*}$ & $-7.00^{* *}$ \\
\hline $\log$ (FOODP) & $\begin{array}{l}\text { Log of the raw price of food, from the } \\
\text { agricultural food component of the CPI }\end{array}$ & 4.08 & 0.613 & -2.32 & $-5.62 * *$ \\
\hline ASYMFOOD & $\begin{array}{l}\text { Asymmetric effect of food price changes: } \\
\Delta \log (\text { FOODP) if } \Delta \log (\text { FOODP })>0 \text {, and zero } \\
\text { otherwise. }\end{array}$ & 0.0519 & 0.0564 & $-7.25^{* *}$ & $-12.2 * *$ \\
\hline GAP & $\begin{array}{l}\text { The output gap measured as: log real GDP } \\
\text { adjusted with a Hodrick Prescott filter } \\
\text { (lambda }=1600 \text { ) for potential GDP }\end{array}$ & 0.114 & 1.67 & $-4.22 * *$ & $-5.70 * *$ \\
\hline RCUSTMA8 & $\begin{array}{l}\text { Tariff measure: ratio of customs earnings to } \\
\text { merchandise imports, } 8 \text {-quarter moving } \\
\text { average. }\end{array}$ & 0.049 & 0.00783 & -2.77 & $-3.00^{*}$ \\
\hline MA4TRVOL & $\begin{array}{l}\text { Conventional trade policy measure in real } \\
\text { terms: ratio of real exports plus real imports } \\
\text { to real GDP, 4-quarter moving average }\end{array}$ & 32.0 & 7.69 & -2.44 & $-3.01 *$ \\
\hline MA4TREND & $\begin{array}{l}\text { Non-tariff barrier measure: quarternalised } \\
\text { stochastic trend, 4-quarter moving average, } \\
\text { from Aron and Muellbauer (2007b). }\end{array}$ & 0.139 & 0.107 & & \\
\hline DUM90Q4 & Impulse dummy for 1990 quarter 4. & & & & \\
\hline DUM02Q1 & Impulse dummy for 2000 quarter 1. & & & & \\
\hline DUM05Q4 & Impulse dummy for 2005 quarter 4. & & & & \\
\hline DUM2000 & $\begin{array}{l}\text { Step dummy, } 0 \text { up to } 1999 \text { quarter } 4,1 \text { from } \\
2000 \text { quarter } 1 \text {. }\end{array}$ & & & & \\
\hline
\end{tabular}

Source: All variables from the Quarterly Bulletin, South African Reserve Bank, except the US T bill and SA prime rates (from IFS, International Monetary Fund). Derivation and motivation for MA4TREND is given in Aron and Muellbauer (2007b). Statistics rounded to three significant figures. The augmented Dickey-Fuller test statistics are based on specifications including a linear trend where this is significant, and lag lengths are based on the longest significant lag. The $\log (\mathrm{ULC})$ test statistic is based on the inclusion of a time trend, though this is not strictly significant. If the trend is excluded, the test would suggest that $\log (\mathrm{ULC})$ is $\mathrm{I}(0)$ but with an implausibly low speed of adjustment. 
Table 3a: The SARB's producer price inflation model enhanced with openness measures over longer samples

\begin{tabular}{|c|c|c|c|c|c|c|c|c|c|c|}
\hline \multirow{3}{*}{$\begin{array}{l}\text { Dependent variable } \\
\Delta \log (\mathrm{WPI})\end{array}$} & \multicolumn{2}{|c|}{1} & \multicolumn{2}{|l|}{2} & \multicolumn{2}{|c|}{3} & \multicolumn{2}{|c|}{4} & \multicolumn{2}{|c|}{5} \\
\hline & \multicolumn{2}{|c|}{ 1990:1 - 2005:4 } & \multicolumn{2}{|c|}{ 1980:1 - 2005:4 } & \multicolumn{2}{|c|}{ 1980:1-2005:4 } & \multicolumn{2}{|c|}{ 1980:1 - 2005:4 } & \multicolumn{2}{|c|}{ 1980:1-2005:4 } \\
\hline & Coeff & $t$ & coeff & $t$ & coeff & $t$ & coeff & $t$ & coeff & $t$ \\
\hline \multicolumn{11}{|c|}{ Long run terms and dummies: } \\
\hline $\mathrm{C}$ & .027 & 2.31 & 0.006 & 0.96 & 0.041 & 2.85 & 0.042 & 2.56 & 0.006 & 0.37 \\
\hline Q1 & 0.0071 & 3.10 & 0.0036 & 1.84 & 0.0037 & 2.00 & 0.0036 & 1.91 & 0.0028 & 1.60 \\
\hline Q4 & 0.0051 & 2.38 & 0.0044 & 2.30 & 0.0040 & 2.19 & 0.0043 & 2.30 & 0.0022 & 1.28 \\
\hline DUM90Q4 & 0.037 & 5.14 & 0.033 & 4.09 & 0.035 & 4.51 & 0.0317 & 4.03 & 0.0354 & 4.91 \\
\hline DUM02Q1 & 0.025 & 3.34 & 0.028 & 3.38 & 0.029 & 3.64 & 0.0287 & 3.54 & 0.0276 & 3.63 \\
\hline $\begin{array}{l}\log (\mathrm{WPI})- \\
0.73 \log (\mathrm{ULC})- \\
0.27 \log (\mathrm{IMPP})(-1)\end{array}$ & -0.054 & 2.80 & -0.016 & -1.54 & -0.068 & -3.53 & -0.0502 & -2.84 & -0.004 & -0.17 \\
\hline \multicolumn{11}{|l|}{ Dynamic terms: } \\
\hline$\Delta \log (\mathrm{IMPP})$ & 0.154 & 6.29 & 0.122 & 6.30 & 0.114 & 6.04 & 0.1218 & 6.42 & 0.111 & 6.00 \\
\hline$\Delta \log (\operatorname{IMPP})(-1)$ & - & - & - & - & - & - & - & - & 0.074 & 3.40 \\
\hline$\Delta \log (\mathrm{WPI})(-1)$ & 0.422 & 5.70 & 0.587 & 9.10 & 0.553 & 8.81 & 0.5684 & 8.97 & 0.391 & 5.58 \\
\hline$\Delta \log (\mathrm{ULC})$ & 0.233 & 3.57 & 0.139 & 2.62 & 0.174 & 3.33 & 0.1602 & 3.04 & 0.009 & 0.14 \\
\hline$\Delta \log (\mathrm{ULC})(-1)$ & 0.191(restric) & & 0.152 (restric) & & 0.159 (restrict) & & & & 0.024 & 0.39 \\
\hline$\Delta \mathrm{GAP}(-1)$ & 0.0053 & 2.94 & 0.0034 & 3.34 & 0.0041 & 4.01 & 0.0037 & 3.67 & 0.0024 & 1.89 \\
\hline \multicolumn{11}{|c|}{ Trade openness measures: } \\
\hline RCUSTMA8(-1) & - & - & - & - & 0.083 & 0.76 & & & 0.152 & 1.42 \\
\hline MA4TREND(-4) & - & - & - & - & -0.039 & -2.91 & & & -0.0297 & -2.33 \\
\hline MA4TRVOL(-1) & - & - & - & - & & & -0.0424 & -2.36 & & \\
\hline \multicolumn{11}{|l|}{ Diagnostics: } \\
\hline Equation std. error & 0.00675 & & 0.00784 & & 0.00753 & & 0.00766 & & 0.00696 & \\
\hline Adjusted $\mathrm{R}^{2}$ & $0.879^{*}$ & & $0.825^{*}$ & & $0.839 *$ & & $0.833^{*}$ & & 0.742 & \\
\hline DW & 2.37 & & 2.31 & & 2.29 & & 2.32 & & 2.00 & \\
\hline Chow (mid-sample) & $\mathrm{p}=0.66$ & & 0.10 & & 0.43 & & 0.39 & & 0.51 & \\
\hline Normality test & $\mathrm{p}=0.90$ & & 0.59 & & 0.62 & & 0.69 & & 0.97 & \\
\hline AR/MA1- test & $\mathrm{p}=0.044$ & & 0.039 & & 0.056 & & 0.045 & & 0.87 & \\
\hline AR/MA4-test & $\mathrm{p}=0.20$ & & 0.18 & & 0.087 & & 0.106 & & 0.20 & \\
\hline hetero test (Breusch) & $\mathrm{p}=0.84$ & & 0.047 & & 0.053 & & 0.056 & & 0.051 & \\
\hline
\end{tabular}


Table 3b: The SARB's producer price inflation model enhanced with openness measures and other variables

\begin{tabular}{|c|c|c|c|c|c|c|c|c|c|c|}
\hline \multirow{3}{*}{$\begin{array}{l}\text { Dependent variable: } \\
\Delta \log (\mathrm{WPI})\end{array}$} & \multicolumn{2}{|c|}{6} & \multicolumn{2}{|c|}{7} & \multicolumn{2}{|c|}{8} & \multicolumn{2}{|c|}{9} & \multicolumn{2}{|r|}{10} \\
\hline & \multicolumn{2}{|c|}{ 1980:1 - 2005:4 } & \multicolumn{2}{|c|}{ 1980:1 - 1999:4 } & \multicolumn{2}{|c|}{ 1980:1 - 2005:4 } & \multicolumn{2}{|c|}{ 1980:1 - 2005:4 } & \multicolumn{2}{|c|}{ 1980:1 -1999:4 } \\
\hline & coeff & $t$ & coeff & $t$ & coeff & $t$ & coeff & $t$ & coeff & $t$ \\
\hline \multicolumn{11}{|c|}{ Long run terms and dummies: } \\
\hline $\mathrm{C}$ & 0.257 & 8.87 & 0.272 & 9.27 & 0.272 & 9.40 & 0.325 & 9.26 & 0.294 & 10.11 \\
\hline Q1 & 0.0028 & 2.55 & 0.0034 & 2.81 & 0.0028 & 2.71 & 0.0030 & 2.55 & 0.0036 & 3.14 \\
\hline DUM90Q4 & 0.036 & 7.47 & 0.036 & 7.53 & 0.035 & 7.33 & 0.028 & 5.29 & 0.035 & 7.71 \\
\hline DUM02Q1 & 0.020 & 3.90 & - & & 0.020 & 3.89 & 0.020 & 3.50 & - & \\
\hline DUM05Q4 & -0.018 & -3.51 & - & & -0.017 & -3.38 & - & & - & \\
\hline DUM2000 & -0.0053 & -2.25 & - & & -0.0046 & -2.00 & -0.0084 & -4.15 & - & \\
\hline $\begin{array}{l}\log (\mathrm{WPI})- \\
0.73 \log (\mathrm{ULC})- \\
0.27 \log (\mathrm{IMPP})(-1)\end{array}$ & -0.047 & -2.77 & -0.052 & -2.73 & -0.070 & -3.66 & -0.098 & -4.05 & -0.0887 & -3.96 \\
\hline $\log (\mathrm{REER})(-1)$ & -0.048 & -10.03 & -0.051 & -10.01 & -0.049 & -10.46 & -0.041 & -8.33 & -0.052 & -10.78 \\
\hline USSPREAD(-1) & -0.102 & -5.48 & -0.101 & -4.05 & -0.114 & -6.06 & -0.107 & -5.55 & -0.133 & -5.03 \\
\hline GAP(-1) & 0.0012 & 3.42 & 0.0013 & 3.94 & 0.0011 & 3.54 & 0.0021 & 4.74 & 0.0014 & 4.31 \\
\hline \multicolumn{11}{|c|}{ Dynamic and asymmetric terms: } \\
\hline$\Delta \log (\mathrm{IMPP})$ & 0.071 & 5.32 & 0.059 & 4.20 & 0.072 & 5.51 & 0.095 & 6.79 & 0.063 & 4.68 \\
\hline$\Delta \log (\mathrm{IMPP})(-1)$ & 0.075 & 5.34 & 0.069 & 4.55 & 0.071 & 5.14 & 0.090 & 6.04 & 0.066 & 4.56 \\
\hline$\Delta 4 \log (\mathrm{ULC})$ & - & & - & & 0.049 & 2.38 & 0.050 & 2.20 & 0.059 & 2.80 \\
\hline ASYMFOOD & 0.069 & 7.55 & 0.083 & 7.90 & 0.069 & 7.76 & 0.063 & 6.57 & 0.087 & 8.58 \\
\hline \multicolumn{11}{|l|}{ Trade policy measures: } \\
\hline RCUSTMA8(-1) & 0.74 & 5.50 & 0.77 & 4.37 & 0.74 & 5.70 & - & & 0.89 & 5.15 \\
\hline MA4TREND(-4) & -0.063 & -6.35 & -0.066 & -6.58 & -0.061 & -6.23 & - & & -0.061 & -6.25 \\
\hline MA4TRVOL(-1) & - & & - & & - & & -0.0138 & -7.60 & - & \\
\hline \multicolumn{11}{|l|}{ Diagnostics: } \\
\hline Equation std. error & 0.00523 & & 0.00454 & & 0.00457 & & 0.00511 & & 0.00433 & \\
\hline Adjusted $\mathrm{R}^{2}$ & 0.855 & & 0.857 & & 0.889 & & 0.861 & & 0.870 & \\
\hline DW & 1.97 & & 1.98 & & 1.98 & & 1.73 & & 2.06 & \\
\hline Chow (mid-sample) & $\mathrm{P}=0.35$ & & 0.09 & & 0.49 & & 0.83 & & 0.16 & \\
\hline Normality test & $\mathrm{P}=0.64$ & & 0.78 & & 0.57 & & 0.77 & & 0.97 & \\
\hline AR/MA1- test & $\mathrm{P}=0.83$ & & 0.96 & & 0.95 & & 0.23 & & 0.77 & \\
\hline AR/MA4-test & $\mathrm{P}=0.45$ & & 0.15 & & 0.42 & & 0.32 & & 0.14 & \\
\hline hetero test (Breusch) & $\mathrm{P}=0.61$ & & 0.43 & & 0.31 & & 0.58 & & 0.33 & \\
\hline
\end{tabular}

